Original paper

\title{
Línekite, $\mathrm{K}_{2} \mathrm{Ca}_{3}\left[\left(\mathrm{UO}_{2}\right)\left(\mathrm{CO}_{3}\right)_{3}\right]_{2} \cdot 8 \mathrm{H}_{2} \mathrm{O}$, a new uranyl carbonate mineral from Jáchymov, Czech Republic
}

\author{
Jakub PLÁŠIL1*, Jiří ČEJKA², Jiří SEJKORA², Jan HLOUŠEK', Radek ŠKODA ${ }^{3}$ Milan NOVÁK \\ Michal DUŠEK', Ivana CÍSAŘOVÁ4, Ivan NĚMEC ${ }^{4}$, Jana EDEROVÁ ${ }^{5}$
}

\author{
${ }^{1}$ Institute of Physics, Academy of Sciences of the Czech Republic v.v.i, Na Slovance 2, 18221 Prague 8, Czech Republic; plasil@fzu.cz \\ ${ }^{2}$ Department of Mineralogy and Petrology, National Museum, Cirkusová 1740, 19300 Prague 9, Czech Republic \\ + Jáchymov; deceased on April 27, 2014 \\ ${ }^{3}$ Department of Geological Sciences, Faculty of Science, Masaryk University, Kotlářská 2, 61137 Brno, Czech Republic \\ ${ }^{4}$ Department of Inorganic Chemistry, Faculty of Science, Charles University, Hlavova 8, 12843 Prague 2, Czech Republic \\ ${ }^{5}$ Institute of Chemical Technology, Technická 5, 16628 Prague 6, Czech Republic \\ * Corresponding author
}

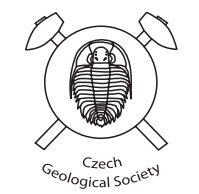

Línekite, $\mathrm{K}_{2} \mathrm{Ca}_{3}\left[\left(\mathrm{UO}_{2}\right)\left(\mathrm{CO}_{3}\right)_{3}\right]_{2} \cdot 8 \mathrm{H}_{2} \mathrm{O}$, is a new uranyl tricarbonate mineral from Jáchymov, Western Bohemia, Czech Republic. It occurs in association with grimselite, andersonite, liebigite, čejkaite, schröckingerite, agricolaite, ježekite and braunerite. Línekite forms from uranium-rich aqueous solutions and its origin is associated with post-mining processes. Línekite is orthorhombic, space group Pnnm, with $a=17.0069(5) \AA, b=18.0273(5) \AA, c=18.3374(5) \AA$ and $V=5622.1(2) \AA^{3}$, and $Z=8$. It forms tabular, mostly isometric crystals, up to $c$. $0.5 \mathrm{~mm}$ across, typically in multiple intergrowths. The color is pale olive to khaki green and it has a greenish white to yellowish white streak. Crystals are transparent and have vitreous luster. The Mohs hardness is estimated to be between 2 and 3. Línekite is brittle with an uneven fracture and perfect cleavage on $\{100\}$ and very good cleavage on $\{010\}$. It exhibits intense greenish yellow luminescence under both short- $(254 \mathrm{~nm})$ and long-wave $(366 \mathrm{~nm})$ UV radiation. The calculated density is $2.922 \mathrm{~g} / \mathrm{cm}^{3}$. The mineral is biaxial $(+)$ with indices of refraction, $\alpha=1.546(2), \beta=1.550, \gamma=1.562(2)$. The $2 V_{\text {obs }}$ is moderate; the calculated $2 \mathrm{~V}$ is $+60^{\circ}$. Optical orientation: $Y=\mathbf{a}, X=\mathbf{b}, Z=\mathbf{c}$. The electron microprobe analyses (average of 28) provided: $\mathrm{Na}_{2} \mathrm{O} 0.06, \mathrm{~K}_{2} \mathrm{O} 6.89, \mathrm{CaO} 14.11, \mathrm{CuO} 0.12, \mathrm{UO}_{3} 48.76, \mathrm{CO}_{2} * 22.51, \mathrm{H}_{2} \mathrm{O} * 12.20$ ( 12.9 from TG) (*calculated), total $104.65 \mathrm{wt} \%$. The empirical formula (based on $30.22 \mathrm{O}$ apfu) is: $\left(\mathrm{K}_{1.73} \mathrm{Na}_{0.02}\right)_{\Sigma 1.75}\left(\mathrm{Ca}_{2.97} \mathrm{Cu}_{0.02}\right)_{\Sigma 2.99}\left[\left(\mathrm{UO}_{2}\right)\left(\mathrm{CO}_{3}\right)_{3}\right]_{2.02}\left(\mathrm{H}_{2} \mathrm{O}\right)_{8.00}$. The Raman and infrared spectra exhibit prominent features consistent with the mineral being a hydrated uranyl tricarbonate, with fundamental vibrations of $\mathrm{H}_{2} \mathrm{O}$ molecules, $\mathrm{CO}_{3}{ }^{2-}$ anions and $\mathrm{UO}_{2}{ }^{2+}$ ions. The seven strongest powder $\mathrm{X}$-ray diffraction lines are $\left[d_{\text {obs }}\right.$ in $\left.\AA(h k l) I_{r e l}\right]: 8.627$ (200) 100, 6.436 (022) 60, 5.935 (212) 11, $5.153(222) 43,4.592$ (004) $19,4.505$ (040) 12 and 4.053 (204) 15. The structure of línekite was refined from single-crystal X-ray data to $R=0.034$ for 4468 unique observed reflections $\left(I_{\text {obs }}>3 \sigma l\right)$. The structure consists of prominent $\left(\mathrm{Ca}\left(\mathrm{H}_{2} \mathrm{O}\right)_{2}\left[\left(\mathrm{UO}_{2}\right)\left(\mathrm{CO}_{3}\right)_{3}\right]\right)^{2-}$ layers parallel to (100), which define a square grid, leading to a strong tetragonal pseudosymmetry of línekite. Between the layers, disordered $\mathrm{K}^{+}$cations and $\mathrm{H}_{2} \mathrm{O}$ molecules are localized. The structure is closely related to other uranyl tricarbonate minerals, e.g., albrechtschraufite and andersonite, due to the presence of a very characteristic paddle-wheel motif, $\mathrm{Ca}\left[\left(\mathrm{UO}_{2}\right)\left(\mathrm{CO}_{3}\right)_{3}\right]_{4} \mathrm{Ca}$.

Keywords: Línekite, uranyl carbonate, crystal structure, Raman spectroscopy, Jáchymov

Received: 11 June 2017; accepted: 21 August 2017; handling editor: F. Laufek

The online version of this article (doi: 10.3190/jgeosci.241) contains supplementary electronic material.

\section{Introduction}

Uranyl carbonate minerals are thermodynamically favored to precipitate from neutral- to alkaline aqueous solutions containing dissolved $\mathrm{CO}_{3}{ }^{2-}$ ions (Langmuir 1978). The activity of carbonate species is usually maintained by the dissolution of gangue carbonates, which are commonly associated with primary uraninite on most hydrothermal veins. Until recently the twenty-six uranyl carbonates have been described as minerals (Krivovichev and Plášil 2013). The Jáchymov ore district is famous namely for the occurrences of uranyl minerals, and among them uranyl carbonates have been of particular interest in the past, as it is well documented e.g. by the early description of the uranyl carbonate-sulfate mineral schröckingerite, already in 1873 (Schrauf 1873; Mereiter 1986a). Several remarkable uranyl carbonate minerals were described from Jáchymov as their type locality; among them albrechtschraufite, $\mathrm{MgCa}_{4} \mathrm{~F}_{2}\left[\left(\mathrm{UO}_{2}\right)\left(\mathrm{CO}_{3}\right)_{3}\right]_{2}\left(\mathrm{H}_{2} \mathrm{O}\right)_{17-18}$ (Mereiter 1984; 2013), čejkaite, $\mathrm{Na}_{4}\left[\left(\mathrm{UO}_{2}\right)\left(\mathrm{CO}_{3}\right)_{3}\right]$ (Ondruš et al. 2003; Plášil et al. 2013) and agricolaite, $\mathrm{K}_{4}\left(\mathrm{UO}_{2}\right)$ $\left.\left(\mathrm{CO}_{3}\right)_{3}\right]$ (Skála et al. 2011). In this paper we provide the description of a new uranyl tricarbonate mineral from Jáchymov, línekite, ideally $\mathrm{K}_{2} \mathrm{Ca}_{3}\left[\left(\mathrm{UO}_{2}\right)\left(\mathrm{CO}_{3}\right)_{3}\right]_{2} \cdot 8 \mathrm{H}_{2} \mathrm{O}$, Strunz Class 05.ED, which is the first member containing alkalis to alkaline earths in the ratio $2: 3$. 
Línekite is named in honor of Dr. Allan Línek (19251984), a Czech physicist and crystallographer of the Institute of Physics, Academy of Sciences of the Czech Republic, for his significant contribution to structure science.

The new mineral and its name have been approved by the Commission on New Minerals, Nomenclature and Classification (CNMNC) of the International Mineralogical Association (IMA 2012-066). The description of the mineral is based upon material from the holotype specimen, which is now deposited in the collections of the Department of Mineralogy and Petrology of the National Museum in Prague, Cirkusová 1740, Prague 9, Czech Republic, catalog number P1P 2/2012.

\section{Sample}

Línekite was discovered in an old mine adit on the Geschieber vein, at the $5^{\text {th }}$ level of the Svornost (Einigkeit) mine, Jáchymov ore district, Western Bohemia, Czech Republic. The mineral was found by one of the authors $(\mathrm{JH})$ on the muddy or dusty surfaces of the surrounding country rocks (dominantly dark amphibole schist) and, less commonly, also in gangue material lying as gravel on the footwall of the crossing-adit leading to the vein. Liebigite, grimselite, andersonite, čejkaite, schröckingerite, agricolaite, ježekite (Plášil et al. 2015), braunerite (IMA 2015-123, Plášil et al. 2016), and gypsum occur closely associated with línekite.

Since no primary uranium mineral or its relics were found on the specimens, we conclude that the mineral assemblage of uranyl carbonates and sulfates formed from U-rich solutions, most probably containing uranyl-carbonate complexes that migrated from the primary sites. These solutions were likely alkaline or neutral. The presence of $\left(\mathrm{SO}_{4}\right)^{2-}$ anions (in schröckingerite and in ježekite) is due to abundance of pyrite in the associated black schist. The mineral assemblage in which línekite occurs is typical of recent/subrecent association related to post-mining processes.

\section{Physical and optical properties}

Línekite occurs as well-formed thin tabular crystals, up to $0.5 \mathrm{~mm}$ in size, forming aggregates of sub-parallel intergrown crystals (Fig. 1). Their aggregates reach up to $1.2 \mathrm{~mm}$ across. Línekite crystals show a dominant $\{100\}$ pinacoid form, and prism forms $\{101\},\{110\}$ and $\{011\}$ (Fig. 2). The color is pale olive to khaki green. The streak is greenish white to yellowish white and luster is vitreous. Línekite exhibits intense greenish yellow luminescence under both short- $(254 \mathrm{~nm})$ and long-wave $(366 \mathrm{~nm}) \mathrm{UV}$ radiation. The Mohs hardness ranges between 2 and 3 . The new mineral is brittle with uneven fracture and a perfect cleavage on $\{100\}$ and a very good cleavage on $\{010\}$. The calculated density based on the empirical formula is $2.922 \mathrm{~g} / \mathrm{cm}^{3}$. The mineral is optically biaxial $(+)$ with the following indices of refraction, measured using $589 \mathrm{~nm}$ light: $\alpha=1.546(2), \beta=1.550, \gamma=1.562(2)$. The index $\beta$ was measured only once due to the lack of appropriately oriented crystal fragments. $2 V_{\text {obs }}$ is moderate but the exact value could not be measured as the conoscopic figures were of a low quality; calculated $2 \mathrm{~V}$ is $+60^{\circ}$. Optical orientation: $Y=\mathbf{a}, X=\mathbf{b}, Z=\mathbf{c}$. Línekite is pale khaki green and non-pleochroic in transmitted light. It dissolves quickly in $10 \% \mathrm{HCl}$ with the release of $\mathrm{CO}_{2}$ observed as bubbles.

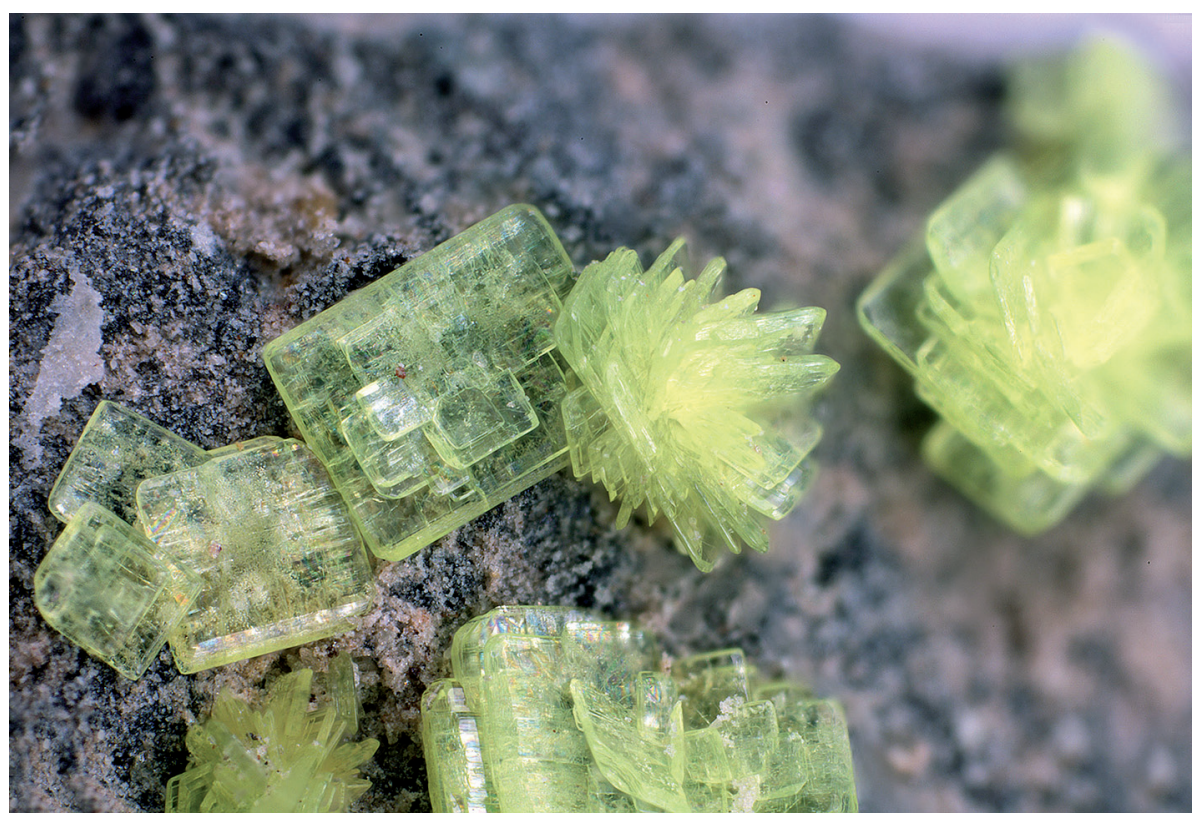

\section{Thermal analysis}

A thermogravimetric study of línekite (Fig. 3) was performed on a Stanton Redcroft Thermobalance TG 750 in the range $20-900^{\circ} \mathrm{C}$, with a heating rate of $10^{\circ} \mathrm{C} / \mathrm{min}$, in a dynamic air atmosphere, a flow rate of $10 \mathrm{ml} / \mathrm{min}$ and a sample weight of $1.422 \mathrm{mg}$.

Thermal experiment documented that línekite dehydrates in three distinct steps (Fig. 3;

Fig. 1 The aggregate of tabular línekite crystals growing on the rock fragment. Width of photograph $2 \mathrm{~mm}$, photo by Pavel Škácha. 
Fig. 2 The aggregate of línekite tabular crystals. Secondary-electron image (Jeol JSM-6370).

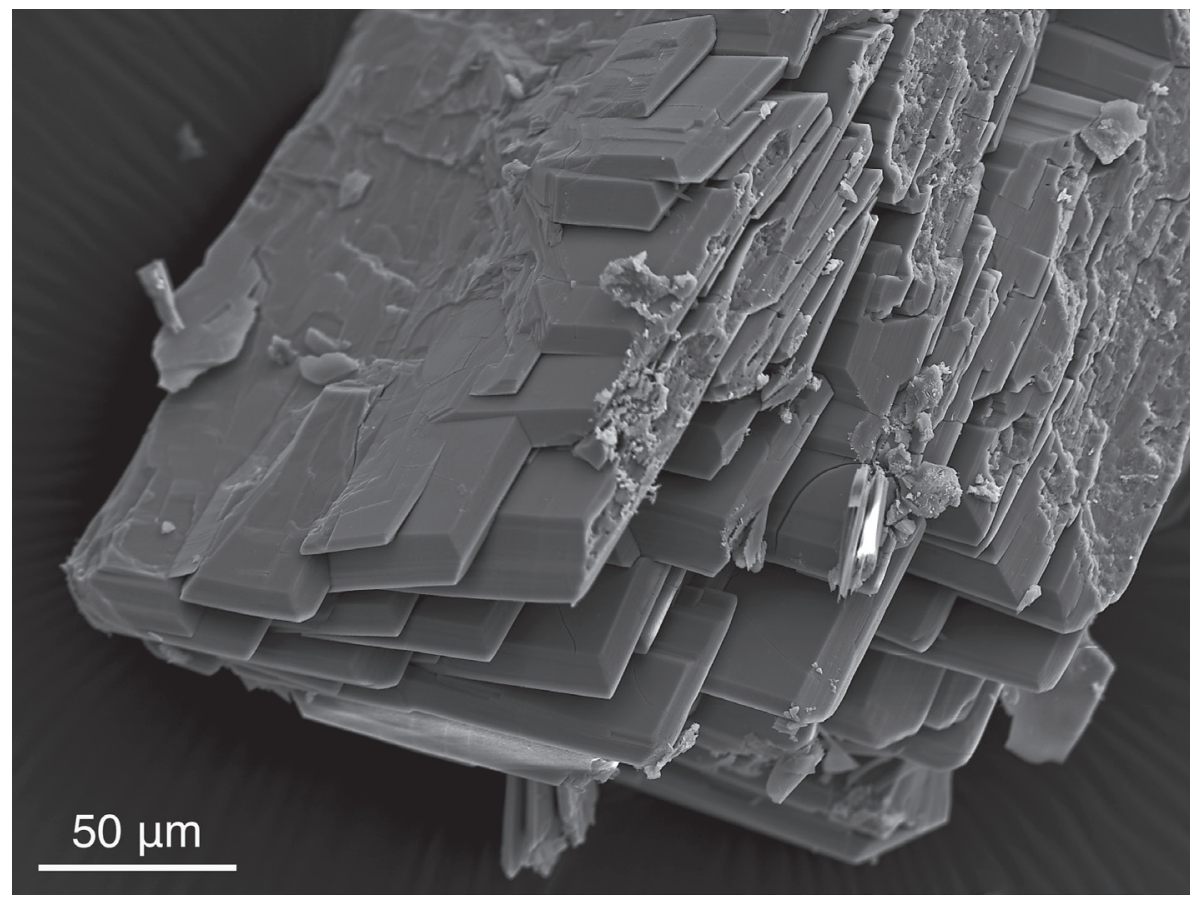

(albite), $\mathrm{K}$ (sanidine); $M_{\beta}$ lines: $\mathrm{U}$ (metallic $\left.\mathrm{U}\right)$. Other elements, including S, Si or Mg were also sought, but they were not found (the detection limits of the analysis for these elements are $\sim 0.1$ wt. \% with the analytical conditions used). Peak counting times were $10-20 \mathrm{~s}$ and the counting time for the background was $50 \%$ of those on the peak. The measured intensities were converted to elemental concentrations using the PAP program (Pouchou and Pichoir 1985).

The results of electron microprobe analyses are summarized in Tab. 2. The empirical formula of línekite (based on $30.22 \mathrm{O}$ apfu) is $\left(\mathrm{K}_{1.73} \mathrm{Na}_{0.02}\right)_{\Sigma 1.75}\left(\mathrm{Ca}_{2.97} \mathrm{Cu}_{0.02}\right)_{\Sigma 2.99}$ is formed (Čejka 1969). The total content of molecular water in línekite inferred from the thermal analysis is $\sim 8 \mathrm{H}_{2} \mathrm{O}$ (Tab. 1).

\section{Chemical composition}

Electron microprobe analyses (28 representative points) were performed at the Masaryk University in Brno using a Cameca SX-100 electron microprobe (WDS mode, $15 \mathrm{kV}, 2 \mathrm{nA}$, $15 \mu \mathrm{m}$ beam diameter). The following X-ray lines and standards were selected to minimize line overlaps; $K_{\alpha}$ lines: $\mathrm{Ca}$ (grossular), $\mathrm{Cu}$ (dioptase), $\mathrm{Na}$

Fig. 3 Thermal gravimetry curves for línekite.

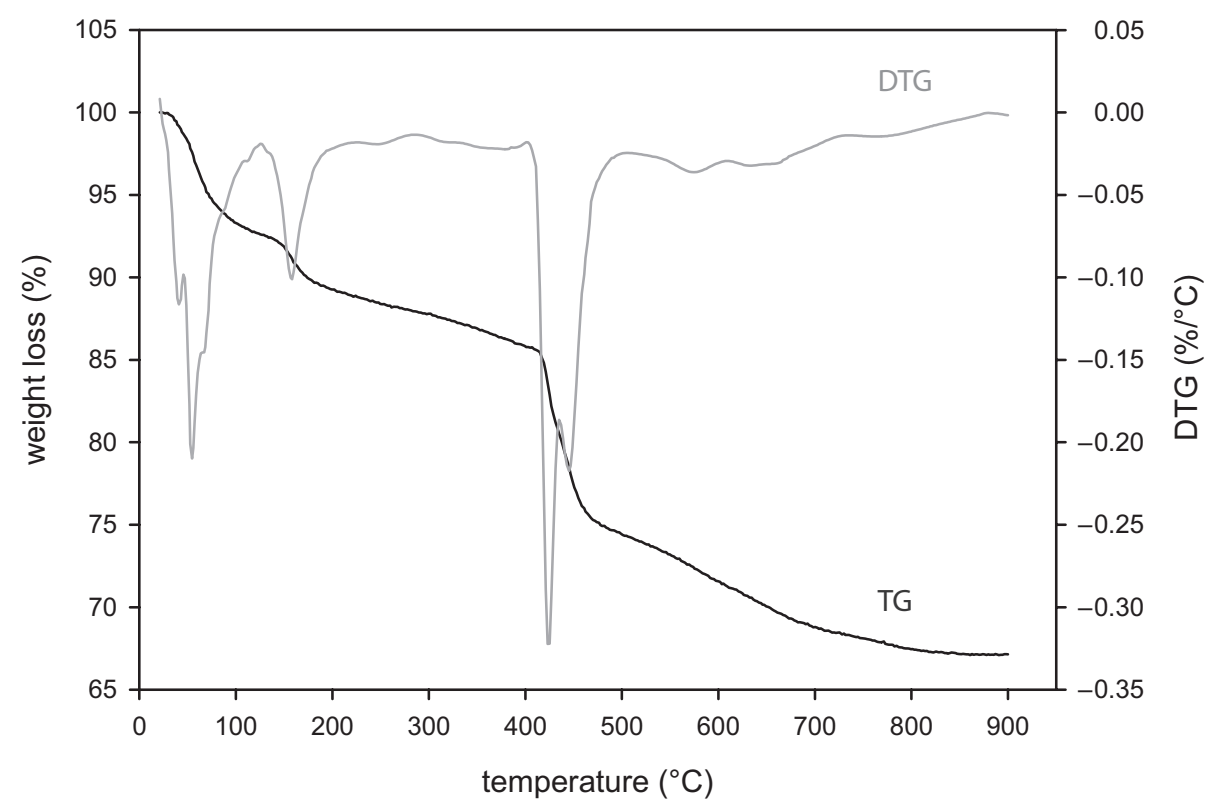


Tab. 1 Thermal analysis of línekite

\begin{tabular}{lccl}
\hline Temperature & Weight loss $($ wt. $\%)$ & Mass units & \multicolumn{1}{c}{ Assignment } \\
\hline 125 & 7.392 & 91.875 & $5 \mathrm{H}_{2} \mathrm{O}\left(\exp .5 .10 \mathrm{H}_{2} \mathrm{O}\right)$ \\
188 & 3.113 & 38.691 & $2 \mathrm{H}_{2} \mathrm{O}\left(2.15 \mathrm{H}_{2} \mathrm{O}\right)$ \\
413 & 3.941 & 48.983 & $1 \mathrm{H}_{2} \mathrm{O}+1 \mathrm{CO}_{2}\left(0.76 \mathrm{H}_{2} \mathrm{O}+0.8 \mathrm{CO}_{2}\right) *$ \\
483 & 10.738 & 133.463 & $3 \mathrm{CO}_{2}\left(3.03 \mathrm{CO}_{2}\right)$ \\
900 & 7.675 & 95.393 & $2 \mathrm{CO}_{2}\left(2.17 \mathrm{CO}_{2}\right)$ \\
\hline total & 32.858 & 408.405 & $8 \mathrm{H}_{2} \mathrm{O}+6 \mathrm{CO}_{2}\left(8.01 \mathrm{H}_{2} \mathrm{O}+6 \mathrm{CO}_{2}\right)$
\end{tabular}

* data assigned tentatively

$\left[\left(\mathrm{UO}_{2}\right)\left(\mathrm{CO}_{3}\right)_{3}\right]_{2.02}\left(\mathrm{H}_{2} \mathrm{O}\right)_{8}$. The basis of $30.22 \mathrm{O}$ in the calculation was chosen due to charge balance. The ideal formula of línekite is $\mathrm{K}_{2} \mathrm{Ca}_{3}\left[\left(\mathrm{UO}_{2}\right)\left(\mathrm{CO}_{3}\right)_{3}\right]_{2} \cdot 8 \mathrm{H}_{2} \mathrm{O}$, which requires $\mathrm{K}_{2} \mathrm{O} 7.58, \mathrm{CaO} 13.54, \mathrm{CO}_{2} 21.25, \mathrm{UO}_{3} 46.03$, $\mathrm{H}_{2} \mathrm{O} 11.60$, total 100.00 wt. \%. The Gladstone-Dale compatibility index $1-\left(K_{\mathrm{p}} / K_{\mathrm{C}}\right)$ is -0.001 for the empirical formula, indicating a superior compatibility (Mandarino 1981).

\section{Raman and infrared spectroscopy}

The Raman spectrum (Fig. 4) of línekite was collected using a DXR dispersive Raman spectrometer (Thermo Scientific) mounted on a confocal Olympus microscope (100× objective). The Raman signal was excited by a 532 $\mathrm{nm}$ diode-pumped solid-state laser and then detected by a CCD detector. Experimental parameters: exposure time, $10 \mathrm{~s}$; number of exposures, 32; grating, 400 lines $/ \mathrm{mm}$; spectrograph aperture, $50 \mu \mathrm{m}$ slit; camera temperature, $-50{ }^{\circ} \mathrm{C}$; laser power level, $3.0 \mathrm{~mW}$. The instrument was calibrated by a software-controlled calibration procedure using multiple neon emission lines (wavelength calibration), multiple polystyrene Raman bands (laser frequency calibration) and standardized white light sources (intensity calibration). For acquiring the infrared spectrum of línekite (Fig. 5), a micro diffuse reflectance infrared Fourier transform spectroscopy (micro-DRIFTS) was utilized. The Thermo Nicolet 6700 FTIR spectrometer (range 4000-600 $\mathrm{cm}^{-1}$, resolution $4 \mathrm{~cm}^{-1}, 128$ scans, Happ-Genzel apodization) equipped with a Spectra Tech InspectIR Plus micro-spectroscopic accessory (mercury-

Tab. 2 Chemical composition of línekite

\begin{tabular}{lccc}
\hline Constituent & Mean of 28 points (wt. \%) & Range & Stand. Dev. \\
\hline $\mathrm{Na}_{2} \mathrm{O}$ & 0.06 & $0.00-0.28$ & 0.07 \\
$\mathrm{~K}_{2} \mathrm{O}$ & 6.89 & $6.53-7.34$ & 0.21 \\
$\mathrm{CaO}$ & 14.11 & $13.28-14.78$ & 0.35 \\
$\mathrm{CuO}$ & 0.12 & $0.00-0.53$ & 0.18 \\
$\mathrm{CO}_{2}{ }^{*}$ & 22.51 & & \\
$\mathrm{UO}_{3}$ & 48.76 & $47.63-50.04$ & 0.59 \\
$\mathrm{H}_{2} \mathrm{O}^{*}$ & 12.20 & & \\
\hline Total & 104.65 & & \\
\hline
\end{tabular}

*Contents of $\mathrm{H}_{2} \mathrm{O}$ * and $\mathrm{CO}_{2}{ }^{*}$ were calculated from stoichiometry derived from the thermal analysis cadmium-telluride detector) was employed. A small amount of the sample was pulverized and mixed with a portion of $\mathrm{KBr}$ and immediately analyzed without preparation the pellet. The same $\mathrm{KBr}$ without the specimen was taken as the blank reference. Spectra were processed (background correction, fitting) using OMNIC Spectral tool software v.7.3 (Thermo Fisher Scientific Inc.). The Raman and infrared spectra of línekite are interpreted with regard to the papers by Koglin et al. (1979), Anderson et al. (1980), and Čejka (1999, 2005).

\section{1. $\mathrm{O}-\mathrm{H}$ vibrations}

The Raman and infrared bands and shoulders in the region above $2500 \mathrm{~cm}^{-1}$ (Raman bands at 3500, 3470, 3270, 3080,2900 and $2740 \mathrm{~cm}^{-1}$ and infrared bands and shoulders at 3590, 3500, 3380, 3220, 3010, 2730 and 2570 $\mathrm{cm}^{-1}$ ) were assigned to $v \mathrm{O}-\mathrm{H}$ stretching frequencies of structurally non-equivalent (symmetrically distinct) $\mathrm{H}_{2} \mathrm{O}$ molecules bonded in the structure by the network of $\mathrm{H}$ bonds. According to the empirical relation provided by Libowitzky (1999), the O‥O separation distances of the hydrogen bonds vary approximately between 2.9 and 2.6 $\AA$ (based on Raman) or between 3.2 and $2.6 \AA$ (based on infrared). A band observed in the Raman spectrum at $1667 \mathrm{~cm}^{-1}$ and infrared bands and shoulders at 1698 , 1654 and $1609 \mathrm{~cm}^{-1}$ are attributed to the $v_{2}(\delta)$ bending vibrations of symmetrically distinct $\mathrm{H}_{2} \mathrm{O}$ molecules. The weak infrared bands at 788 and at $623 \mathrm{~cm}^{-1}$ may be connected with libration modes of $\mathrm{H}_{2} \mathrm{O}$.

\section{2. $\mathrm{CO}_{3}{ }^{2-}$ vibrations}

Raman bands and shoulders at 1590, 1564, 1392 and $1346 \mathrm{~cm}^{-1}$ and infrared bands at 1580, 1553, 1522, 1389 and $1364 \mathrm{~cm}^{-1}$ are attributed to the $v_{3}$ antisymmetric stretching vibrations of structurally nonequivalent $\mathrm{CO}_{3}$ planar groups. The observed splitting of the $v_{3}$ bands indicates the presence of bidentately bonded carbonate groups onto uranyl hexagonal bipyramids in the crystal structure.

Raman bands and shoulders at 1095, 1085 and 1070 $\mathrm{cm}^{-1}$ and infrared band at $1069 \mathrm{~cm}^{-1}$ were assigned to the $v_{1}$ symmetric stretching vibration of the $\mathrm{CO}_{3}$ groups. The Raman band at $836 \mathrm{~cm}^{-1}$ and infrared bands at 853 and $833 \mathrm{~cm}^{-1}$ are attributed to the ${ }_{2}(\delta)$ out-of-plane bending vibration of $\mathrm{CO}_{3}$. Some overlap of the $\mathrm{v}_{2}(\delta) \mathrm{CO}_{3}$ bending vibration with the $v_{1} \mathrm{UO}_{2}{ }^{2+}$ symmetric stretching vibration can be expected. Raman bands and shoulders 
Fig. 4 Raman spectrum of línekite.

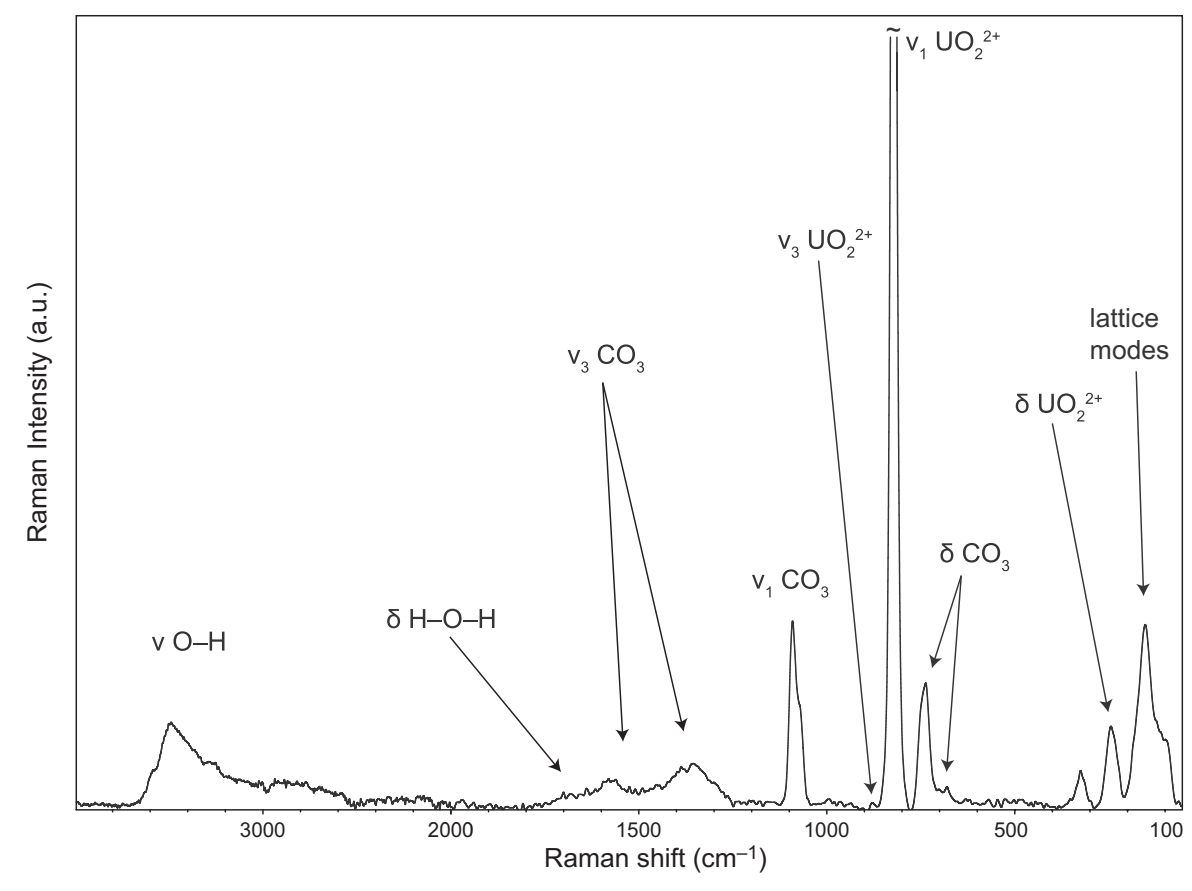

at $750,735,704$ and $680 \mathrm{~cm}^{-1}$ and infrared bands at 752 , 738,694 and $658 \mathrm{~cm}^{-1}$ are assigned to the $v_{4}(\delta)$ in-plane bending $\mathrm{CO}_{3}$ vibration.

\subsection{Vibrations of $\mathrm{UO}_{2}^{2+}$}

The Raman band at $822 \mathrm{~cm}^{-1}$ and infrared band at 809 $\mathrm{cm}^{-1}$ belong to the $v_{1}$ symmetric stretching mode of $\mathrm{UO}_{2}^{2+}$ and an infrared band at $892 \mathrm{~cm}^{-1}$ to the $v_{3}$ antisymmetric stretching mode of $\mathrm{UO}_{2}{ }^{2+}$. As noted above, some overlap with the $v_{2}$ of $\mathrm{CO}_{3}$ cannot be excluded. According to the relation provided by Bartlett and Cooney (1989), U-O bond lengths inferred from the wavenumbers of uranyl stretching vibrations vary in the range of $1.78-1.80 \AA$. Those values are in agreement with the values given by Burns et al. (1997) for uranyl ions coordinated in hexagonal bipyramids. The Raman bands at 339, 324 and 298 $\mathrm{cm}^{-1}$ may be related to the $v$ $\left(\mathrm{U}-\mathrm{O}_{\text {ligand }}\right)$ stretching vibrations and those bands at 249 and 236 $\mathrm{cm}^{-1}$ are connected with the $v_{2}$ $(\delta)$ bends of uranyl. However, some overlaps may be expected in this spectral region. Bands at the lowest wavenumbers were assigned to lattice modes.

Fig. 5 The infrared spectrum of línekite.

\section{X-ray crystallography and crystal structure}

Powder x-ray diffraction data of línekite were collected from a capillary sample in Debye-Scherrer geometry using a PANalytical Empyrean powder diffractometer equipped with a $\mathrm{Cu}$ X-ray tube $(45 \mathrm{kV}, 40 \mathrm{~mA})$, PIXcel3D solid-state detector and primary focusing Göbel mirror optics. The powder pattern was measured from 3 to $80^{\circ} 2 \theta$ with a step size $0.013^{\circ} 2 \theta$ and a counting time $1 \mathrm{~s}$ per step. The repeated scan option was utilized

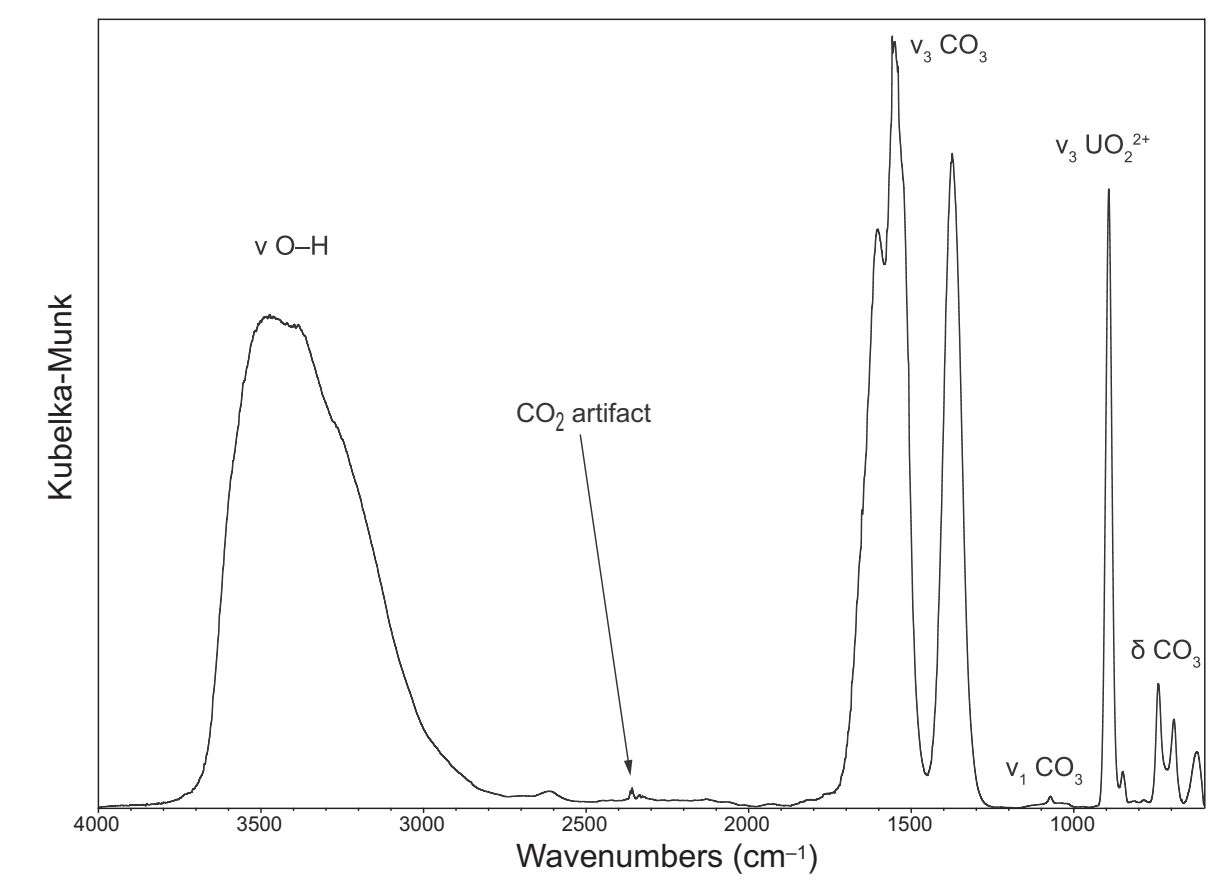


Tab. 3 Powder X-ray diffraction data $\left(d_{h k l}\right.$ in $\left.\AA\right)$ for línekite

\begin{tabular}{|c|c|c|c|c|c|c|c|c|}
\hline \multirow[b]{2}{*}{$\underline{I_{\mathrm{rel}}}$} & \multicolumn{4}{|c|}{ Línekite (this paper) } & \multirow[b]{2}{*}{$\mathrm{k}$} & \multirow[b]{2}{*}{$l$} & \multicolumn{2}{|c|}{ Meyrowitz et al. (1964) } \\
\hline & $d_{\mathrm{obs}}$ & $d_{\text {calc }}$ & $I_{\text {calc }}$ & $\mathrm{h}$ & & & $d_{\mathrm{obs}}$ & $I_{\mathrm{rel}}$ \\
\hline 1 & 10.306 & 10.316 & 2 & 1 & 1 & 1 & & \\
\hline 1 & 9.186 & 9.183 & 3 & 0 & 0 & 2 & & \\
\hline 100 & 8.627 & 8.627 & 100 & 2 & 0 & 0 & 8.70 & 100 \\
\hline 60 & 6.436 & 6.435 & 84 & 0 & 2 & 2 & 6.40 & 36 \\
\hline 4 & 6.231 & 6.234 & 7 & 2 & 2 & 0 & 6.25 & 4 \\
\hline 9 & 6.028 & 6.029 & 3 & 1 & 2 & 2 & 6.03 & 7 \\
\hline 11 & 5.935 & 5.937 & 21 & 2 & 1 & 2 & 5.95 & 13 \\
\hline 2 & 5.712 & 5.715 & 2 & 0 & 3 & 1 & 5.73 & 4 \\
\hline 8 & 5.492 & 5.495 & 16 & 1 & 1 & 3 & 5.50 & 11 \\
\hline 3 & 5.422 & 5.425 & 9 & 1 & 3 & 1 & 5.43 & 4 \\
\hline 43 & 5.153 & 5.158 & 98 & 2 & 2 & 2 & 5.17 & 46 \\
\hline 5 & 4.932 & 4.933 & 11 & 2 & 3 & 0 & 4.94 & 6 \\
\hline 1 & 4.858 & 4.860 & 2 & 1 & 2 & 3 & & \\
\hline 1 & 4.710 & 4.689 & $<1$ & 3 & 2 & 1 & & \\
\hline 19 & 4.592 & 4.591 & 30 & 0 & 0 & 4 & 4.60 & 31 \\
\hline 12 & 4.505 & 4.510 & 23 & 0 & 4 & 0 & 4.51 & 11 \\
\hline 8 & 4.360 & 4.346 & 2 & 2 & 3 & 2 & 4.37 & 11 \\
\hline 6 & 4.311 & 4.313 & 5 & 4 & 0 & 0 & 4.32 & 20 \\
\hline 5 & 4.195 & 4.195 & 5 & 4 & 1 & 0 & 4.21 & 14 \\
\hline 3 & 4.153 & 4.163 & $<1$ & 1 & 3 & 3 & 4.17 & 4 \\
\hline 5 & 4.083 & 4.083 & 4 & 3 & 1 & 3 & & \\
\hline 15 & 4.053 & 4.053 & 22 & 2 & 0 & 4 & 4.06 & 24 \\
\hline 10 & 3.996 & 3.997 & 20 & 2 & 4 & 0 & 4.00 & 11 \\
\hline 5 & 3.953 & 3.954 & 8 & 2 & 1 & 4 & & \\
\hline 4 & 3.903 & 3.904 & 4 & 4 & 0 & 2 & & \\
\hline 5 & 3.813 & 3.816 & 8 & 4 & 1 & 2 & & \\
\hline 3 & 3.786 & 3.801 & 5 & 3 & 2 & 3 & & \\
\hline 2 & 3.703 & 3.697 & 2 & 2 & 2 & 4 & & \\
\hline 11 & 3.583 & 3.583 & 27 & 4 & 2 & 2 & & \\
\hline 4 & 3.549 & 3.549 & 2 & 3 & 4 & 0 & & \\
\hline 4 & 3.525 & 3.523 & 6 & 1 & 1 & 5 & & \\
\hline 7 & 3.504 & 3.505 & 16 & 4 & 3 & 0 & & \\
\hline 4 & 3.480 & 3.484 & 3 & 3 & 4 & 1 & & \\
\hline 1 & 3.392 & 3.391 & 2 & 5 & 0 & 1 & & \\
\hline 2 & 3.339 & 3.338 & 1 & 1 & 2 & 5 & & \\
\hline 4 & 3.275 & 3.274 & 5 & 4 & 3 & 2 & & \\
\hline 4 & 3.218 & 3.217 & 9 & 0 & 4 & 4 & & \\
\hline 1 & 3.163 & 3.163 & 1 & 1 & 4 & 4 & & \\
\hline 3 & 3.144 & 3.144 & 6 & 4 & 0 & 4 & & \\
\hline 3 & 3.118 & 3.117 & 12 & 4 & 4 & 0 & & \\
\hline 8 & 3.097 & 3.097 & 9 & 4 & 1 & 4 & & \\
\hline 4 & 3.061 & 3.061 & 3 & 0 & 0 & 6 & & \\
\hline 2 & 3.044 & 3.051 & 2 & 3 & 1 & 5 & & \\
\hline 4 & 3.015 & 3.015 & 9 & 2 & 4 & 4 & & \\
\hline 1 & 2.992 & 2.993 & $<1$ & 5 & 3 & 0 & & \\
\hline 2 & 2.963 & 2.962 & 1 & 1 & 6 & 0 & & \\
\hline 1 & 2.955 & 2.952 & 1 & 4 & 4 & 2 & & \\
\hline 1 & 2.926 & 2.924 & 1 & 1 & 6 & 1 & & \\
\hline 5 & 2.900 & 2.899 & 10 & 0 & 2 & 6 & & \\
\hline 1 & 2.877 & 2.885 & 1 & 2 & 0 & 6 & & \\
\hline 5 & 2.862 & 2.857 & 10 & 0 & 6 & 2 & & \\
\hline 7 & 2.853 & 2.852 & 7 & 5 & 2 & 3 & & \\
\hline 5 & 2.843 & 2.849 & 4 & 2 & 1 & 6 & & \\
\hline 8 & 2.820 & 2.819 & 3 & 1 & 6 & 2 & & \\
\hline
\end{tabular}

$d$ values quoted in $\AA$ to improve the counting statistics with an accumulation of 40 scans. Before the measurement, the diffractometer was calibrated against a $\mathrm{LaB}_{6}$ capillary standard. Positions of the diffraction peaks were refined using the pseudo-Voigt profile function using least-squares of the High-Score Plus program (PANalytical). The unit cell parameters were refined from the powder data by Celref program (Laugier and Bochu 2014) using the diffraction peaks up to $45^{\circ} 2 \theta$ (99 diffractions). The $h k l$ indices were taken from the calculated powder diffraction pattern obtained from the PowderCell program (Kraus and Nolze 1996). The refined unitcell parameters of línekite are: $a=17.254(4) \AA, b=18.040(4) \AA$, $c=18.366(4) \AA$ and $V=5717(2)$ $\AA^{3}$. The powder data for línekite are listed in Tab. 3 .

A $0.31 \times 0.25 \times 0.11 \mathrm{~mm}$ large green crystal of línekite was selected for the single-crystal $\mathrm{X}$-ray diffraction experiment using an Oxford diffraction Gemini single-crystal diffractometer, with monochromated $\operatorname{Mo} K$ radiation $(\lambda=0.71073 \AA$; $55 \mathrm{kV}, 38 \mathrm{~mA}$ ) from a sealed $\mathrm{X}$-ray tube monochromatized with a graphite monochromator, collimated with a fiberoptics Mo-Enhance collimator, and detected with an a Atlas CCD detector. The best crystal selected for the diffraction experiment was, however, found to be a split crystal with partially overlapping reflections. A twin-matrix for determining the overlaps of partially and fully separated reflections was later used in the refinement of the structure. The crystallographic details with the parameters for the data collection and refinement are listed in Tab. 4. The intensity data were corrected 
for Lorentz factor, polarization and background. The absorption correction, combining numerical shape-based correction and the empirical scaling, was done in Jana2006 software (Petrríček et al. 2014), leading to the $R_{\text {int }}$ $=0.046$.

The structure of línekite was solved independently from the known structure of the synthetic phase (Hughes-Kubatko and Burns 2004). The refinement of that model in Jana2006 software (Petříček et al. 2014), using our dataset, led only to the lesssatisfactory results, corresponding to higher residuals: the $R\left(\left[I_{\text {obs }}>3 \sigma(I)\right]\right)=0.049$ and $w R\left(\left(\left[I_{\mathrm{obs}}>3 \sigma(I)\right]\right)=0.119\right.$ with $\mathrm{GOF}=2.15$; maximal and minimal peaks in the differenceFourier electron-density were 4.93 and -2.53 e $\AA^{-3}$. Therefore a new structure solution was carried out using SIR2002 software (Burla et al. 2003) in the space group Pnnm, which was chosen based on the reflection conditions. The model obtained was subsequently refined in Jana2006 using a full-matrix least-squares algorithm based on $F^{2}$ employed therein. The refinement confirmed that the structure of línekite is extremely pseudosymmetric and contains a high degree of disorder, involving especially disordered $\mathrm{C}, \mathrm{O}$ sites (of the $\mathrm{H}_{2} \mathrm{O}$ molecules), and $\mathrm{K}$ sites, with considerably lowered occupations of the corresponding sites. That disorder corresponds to larger differences between línkeite structure and the structure of the synthetic phase, which is also responsible for the less accuracy of the refinement while using the structure of synthetics as a starting model for the least-squares refinement. The final cycle of the refinement converged with the residuals $R$ $\left(\left[I_{\text {obs }}>3 \sigma(I)\right]\right)=0.0340$ and $w R\left(\left[I_{\text {obs }}>3 \sigma(I)\right]\right)=0.0783$ with $\mathrm{GOF}=1.82$; maximal and minimal peaks in the difference-Fourier electron-density were 3.00 and -1.12

Tab. 3 Continued

$d$ values quoted in $\AA$

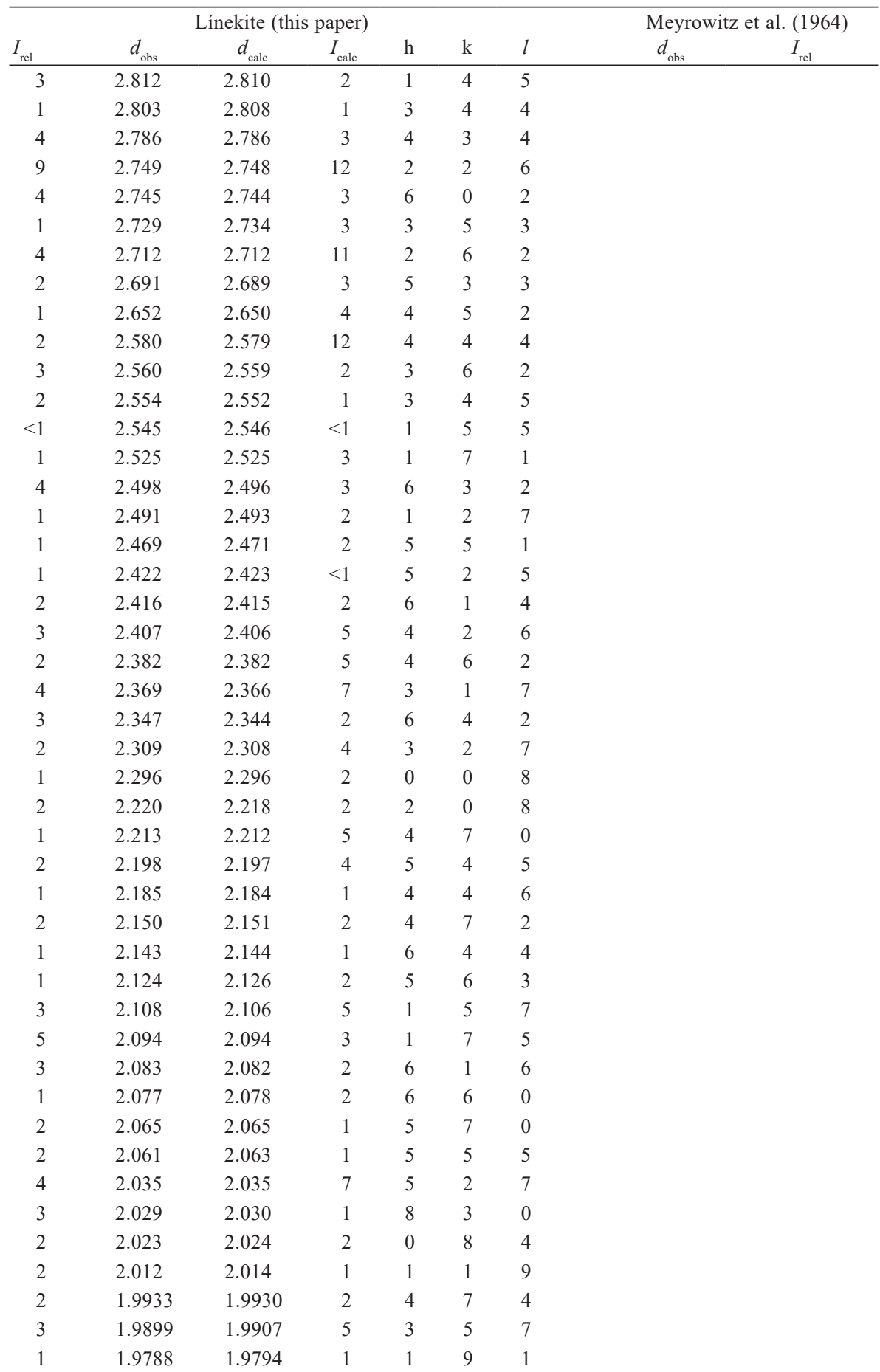

e $\AA^{-3}$. Refined atom coordinates, displacement parameters, and occupation factors are given in Tab. 5. The bond-valence analysis of the structure was carried out following the procedure of Brown (1981, 2002), based on the refined interatomic distances (Electronic Supplementary Material 1), and is provided in the Electronic 
Tab. 4 Data collection and structure refinement for línekite

\begin{tabular}{|c|c|}
\hline \multicolumn{2}{|l|}{ Crystal data } \\
\hline Formula & \multirow{2}{*}{$\begin{array}{l}\mathrm{K}_{1.952} \mathrm{Ca}_{3}\left[\left(\mathrm{UO}_{2}\right)\left(\mathrm{CO}_{3}\right)_{3}\right]_{2}\left(\mathrm{H}_{2} \mathrm{O}\right)_{7.164} \\
\text { orthorhombic }\end{array}$} \\
\hline Crystal system & \\
\hline Space group & Pnnm \\
\hline Unit-cell parameters: $a, b, c[\AA]$ & $17.0069(5), 18.0273(5), 18.3374(5)$ \\
\hline Unit-cell volume $\left[\AA^{3}\right]$ & $5622.0(3)$ \\
\hline $\mathrm{Z}$ & 8 \\
\hline Calculated density $\left[\mathrm{g} / \mathrm{cm}^{3}\right]$ & 2.904 (for the above given formula) \\
\hline Crystal size $[\mathrm{mm}]$ & $0.31 \times 0.25 \times 0.11$ \\
\hline \multicolumn{2}{|l|}{ Data collection } \\
\hline Diffractometer & Oxford Diffraction Gemini with Atlas detector \\
\hline Temperature $[\mathrm{K}]$ & 300 \\
\hline Radiation, wavelength $[\AA]$ & $\mathrm{Mo} K_{\alpha}, 0.71073(50 \mathrm{kV}, 30 \mathrm{~mA})$ \\
\hline$\theta$ range for data collection $\left[{ }^{\circ}\right]$ & 2.7728 .40 \\
\hline Limiting Miller indices & $h=-15 \rightarrow 21, k=-23 \rightarrow 20, l=-23 \rightarrow 23$ \\
\hline Axis, frame width $\left({ }^{\circ}\right)$, time per frame (s) & $\omega, 1.0,100$ \\
\hline Total reflections collected & 34219 \\
\hline Unique reflections & 6179 \\
\hline Unique observed reflections, criterion & $4468,[I>3 \sigma(I)]$ \\
\hline Absorption coefficient $\left[\mathrm{mm}^{-1}\right]$, type & 12.942, multi-scan \\
\hline$T_{\min } / T_{\max }$ & $0.097 / 0.344$ \\
\hline$R_{\text {int }}$ & 0.046 \\
\hline$F_{000}$ & 4405 \\
\hline Structure refinement by Jana2006 & Full-matrix least-squares on $F^{2}$ \\
\hline No. of ref. param., restraints, constraints & $429,0,6$ \\
\hline$R, w R$ (obs) & $0.0339,0.0782$ \\
\hline$R, w R$ (all) & $0.0545,0.0839$ \\
\hline GOF obs/all & $1.82,1.64$ \\
\hline Weighting scheme, weights & $\sigma, w=1 /\left(\sigma^{2}(I)+0.0004 I^{2}\right)$ \\
\hline Largest diff. peak and hole $\left(\mathrm{e}^{-} / \AA^{3}\right)$ & $-1.26,3.61$ \\
\hline Twin fractions & $0.93(1), 0.07(1)$ \\
\hline \multirow{3}{*}{ Twin matrix } & $\left(\begin{array}{ccc}1 & -0.02 & -0.04\end{array}\right)$ \\
\hline & $0.03 \quad 1$ \\
\hline & 0.05 \\
\hline
\end{tabular}

attached bidentately to the bipyramid to form the uranyl tricarbonate cluster, $\left[\left(\mathrm{UO}_{2}\right)\left(\mathrm{CO}_{3}\right)_{3}\right]^{4-}$. There are four disordered (split) $\mathrm{CO}_{3}$ groups, $\mathrm{C} 5$ and C5', C7 and C7', linked to the U2 and U3 hexagonal bipyramids. The uranyl tricarbonate clusters are not attached directly to each other, but through the $\mathrm{Ca}-\mathrm{O}$ bonds they are connected into sheets stacked perpendicular to a.

The four sites, occupied by $\mathrm{Ca}^{2+}$, are coordinated in a distinct way in the línekite structure (Fig. 6). The Ca1 site is coordinated by seven ligands including one $\mathrm{H}_{2} \mathrm{O}$ group $(\mathrm{O} 26 \mathrm{w})$ linked to the four $\mathrm{U}^{6+}$ sites. The $\mathrm{Ca} 2$ site is also linked to the four $\mathrm{U}^{6+}$ sites (symmetrically related U1 sites, U2 and U3), coordinated by seven ligands, including one $\mathrm{H}_{2} \mathrm{O}$ group $(\mathrm{O} 27 \mathrm{w})$, linking the $\mathrm{K} 5$ site. The $\mathrm{Ca} 3$ site is located at the mirror plane and is coordinated by the six ligands (three of them are split sites), linked to the four $\mathrm{U}^{6+}$ sites (symmetrically related U1 sites, U2 and U3). Among the ligands linked to the $\mathrm{Ca} 3$ site we can observe increased disorder manifested in large thermal parameters for the O24/O24', O27w/O27w', and $\mathrm{O} 31 \mathrm{w} / \mathrm{O} 31 \mathrm{w}$ ' atoms, modeled in the current refinement as the split sites. Finally, the Ca4 site is linked only to a single U site (U3) via symmetrically related $\mathrm{O} 22$ atom and further coordinated by seven ligands, including positionally disordered $\mathrm{H}_{2} \mathrm{O}$

Supplementary Material 2. Moreover, the CIF file, also containing a block with the reflections, is deposited at the Journal's web page www.jgeosci.org.

\subsection{Crystal structure}

There are three $\mathrm{U}^{6+}$ sites, nine $\mathrm{C}^{4+}$ sites (including two split-sites; positionally disordered from their corresponding special positions at the mirror planes), four $\mathrm{Ca}^{2+}$ sites, six $\mathrm{K}^{+}$sites and thirty-seven $\mathrm{O}$ sites (including split-sites), eleven of which are occupied by the molecular $\mathrm{H}_{2} \mathrm{O}$.

The three independent $\mathrm{U}^{6+}$ sites are each coordinated by two, strongly bonded $\mathrm{O}$ atoms at the distance of $\sim 1.8 \AA$ (Electronic Supplementary Material 1), forming uranyl ions, $\mathrm{UO}_{2}{ }^{2+}$. These are in turn further coordinated by six $\mathrm{O}$ atoms, arranged at the equatorial vertices of hexagonal bipyramids. Each bipyramid is chelated by three $\mathrm{CO}_{3}$ groups molecules (O31w and O31w', modeled as split-sites). All $\mathrm{Ca}^{2+}$ sites were found to be fully occupied. Linkage of the uranyl tricarbonate clusters and $\mathrm{Ca}^{2+}$ polyhedra results in the sheets, stacked along (100), which are the most rigid part of the línekite structure. The basic unit of these compact regions in the structure is a cluster we refer to as paddle-wheel structure, where two $\mathrm{Ca}^{2+}(\mathrm{Ca} 1$ and $\mathrm{Ca} 2)$ are linked via four $\mathrm{CO}_{3}$ groups of four distinct $\left[\left(\mathrm{UO}_{2}\right)\left(\mathrm{CO}_{3}\right)_{3}\right]^{4-}$ clusters (Fig. 6). In línekite, each uranyl tricarbonate cluster is a part of two paddle-wheels (Fig. 7) that link them into a square-grid (Fig. 8a), composed of the orthorhombic-distorted tetragonal $\mathrm{Ca}_{2}\left(\mathrm{H}_{2} \mathrm{O}\right)_{2}\left[\left(\mathrm{UO}_{2}\right)\right.$ $\left.\left(\mathrm{CO}_{3}\right)_{3}\right]_{2}$ layers, leading to strongly pseudo-tetragonal diffraction pattern (Fig. 8b). The paddle-wheel motif is characteristic of related uranyl carbonate minerals and compounds (Vochten et al. 1994; Mereiter 1986b; Hughes-Kubatko and Burns 2004; Mereiter 2013). 


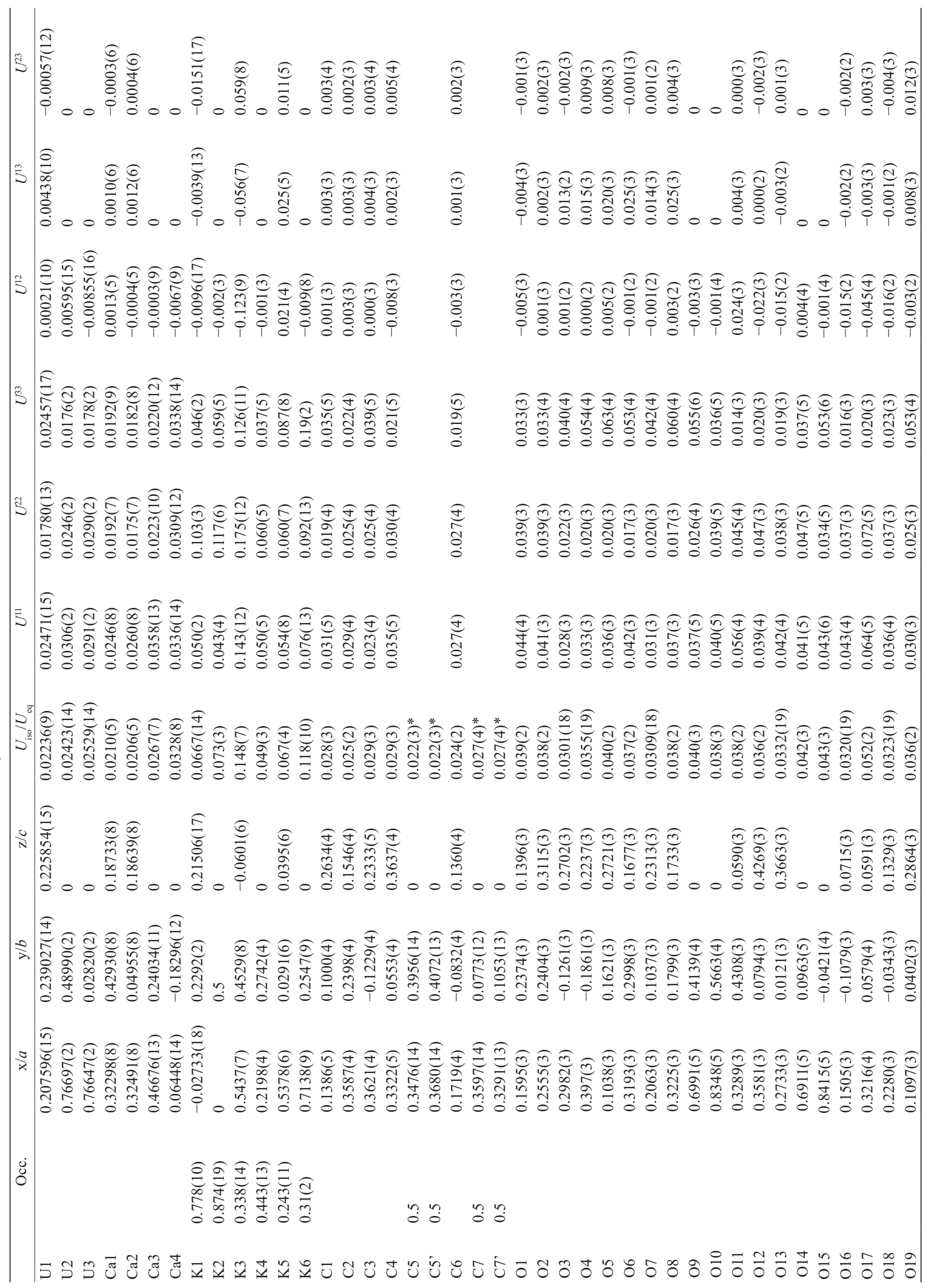




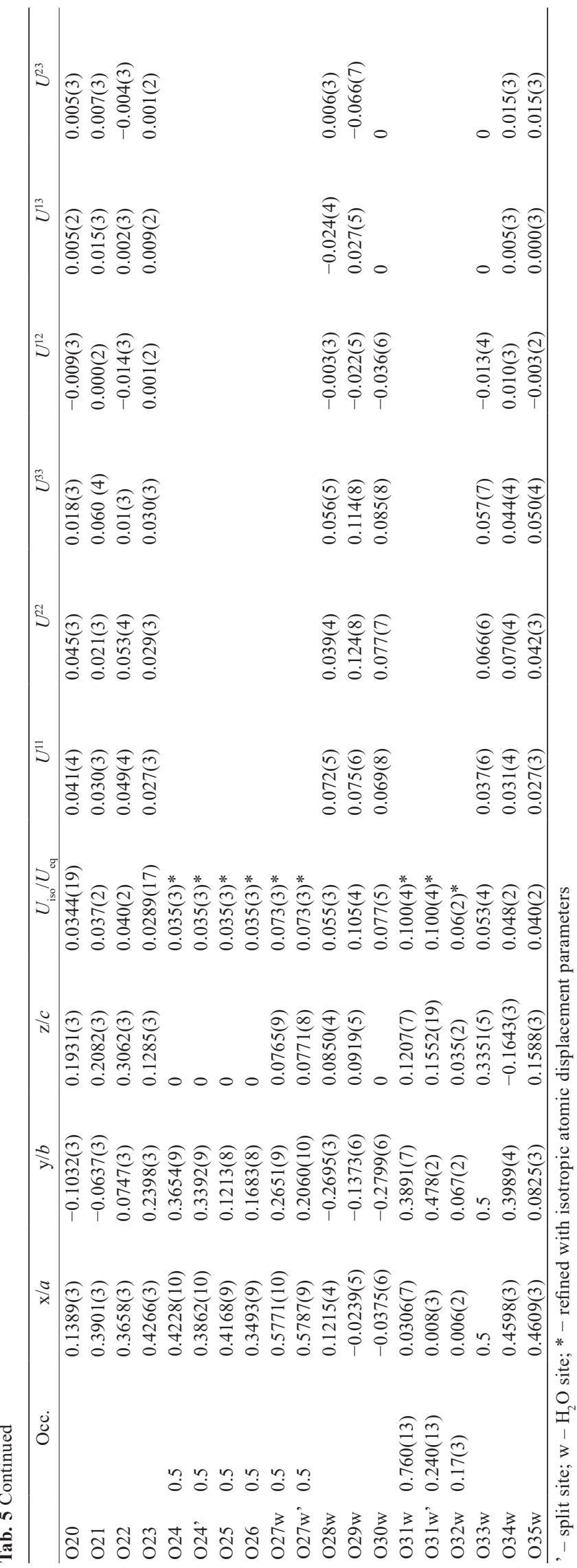

There are six sites in the structure of línekite, occupied by $\mathrm{K}^{+}$cations. All sites have reduced occupancies, as documented from the site-scattering, varying from $\sim 85 \%$ to $\sim 25 \%$ site-occupancy. Hydrated potassium cations represent the least firm part of the structure. The refinement $\mathrm{K}$ and $\mathrm{O}$ atoms (of the $\mathrm{H}_{2} \mathrm{O}$ groups) is particularly difficult due to driven pseudosymmetry of just slightly orthorhombic-distorted tetragonal $\mathrm{Ca}_{2}\left(\mathrm{H}_{2} \mathrm{O}\right)_{2}\left[\left(\mathrm{UO}_{2}\right)\right.$ $\left.\left(\mathrm{CO}_{3}\right)_{3}\right]_{2}$ layers. The assignment of whether the site is dominantly occupied by $\mathrm{H}_{2} \mathrm{O}$ and/or $\mathrm{K}^{+}$, is conclusively not straightforward in the case of línekite. Here in case of such pseudosymmetry, the fact that $\mathrm{K}-\mathrm{O}$ bond lengths are similar to the $\mathrm{O} \cdots \mathrm{O}$ distances for the hydrogen-bonded $\mathrm{H}_{2} \mathrm{O}$ molecules makes the entire issue difficult. The current approach resulting in the presented structure model is based on the fact that disordered $\mathrm{K}$ or $\mathrm{Ca}$ atoms still tend to provide sharper Fourier peaks than the disordered $\mathrm{H}_{2} \mathrm{O}$ molecules. The effect of pseudosymmetry in línekite can be demonstrated on the $\mathrm{K} 2$ site and its coordination environment in particular. The $\mathrm{K} 2$ sitting on a mirror plane is coordinated by fourteen ligands, among them, eight are symmetrically related split atom sites (O32w, O32w'). We can also view it as that the $\mathrm{K} 2$ coordination polyhedra are squeezed between two paddle-wheel structures, which can induce such disorder in coordinated, partly occupied $\mathrm{H}_{2} \mathrm{O}$ sites. The final content of $\mathrm{K}^{+}$per unit cell obtained from the site-scattering refinement is 1.952 atoms, which is nearly the ideal stoichiometric content.

The eleven $\mathrm{O}$ sites in línekite structure, including split-sites, belong to the molecular $\mathrm{H}_{2} \mathrm{O}$, according to the bond-valence analysis (Electronic Supplementary Material 2) and the coordination scheme. Except for O34w atom, located in the cavity of the framework, all other $\mathrm{O}$ sites occupied by $\mathrm{H}_{2} \mathrm{O}$ molecules are coordinated to $\mathrm{Ca}^{2+}$ and namely to $\mathrm{K}^{+}$cations. The majority of $\mathrm{H}_{2} \mathrm{O}$ molecules in the structure are positionally disordered and have also a considerably lowered occupation. The phenomenon mentioned above is driven again by the strong pseudosymmetry of $\mathrm{Ca}_{2}\left(\mathrm{H}_{2} \mathrm{O}\right)_{2}\left[\left(\mathrm{UO}_{2}\right)\left(\mathrm{CO}_{3}\right)_{3}\right]_{2}$ layers where no desymmetrization takes place. The only ordered and fully occupied $\mathrm{H}_{2} \mathrm{O}$ sites are coordinated to $\mathrm{Ca}^{2+}$ cations within the layers. The refinement of the $\mathrm{O}$ site occupancies, associated with the $\mathrm{H}_{2} \mathrm{O}$ sites, yielded the sum of $7.164 \mathrm{H}_{2} \mathrm{O}$ per the unit cell.

\section{Discussion - relationship to the synthetic analogs and other uranyl carbonates, the stoichiometry and the water content of línekite}

Línekite, the synthetic phase prepared by Meyrowitz et al. (1964) and the synthetics by Hughes-Kubatko and Burns (2004) are essentially isostructural. The synthetic 
Fig. 6 The (100) sheet of the nominal composition $\left\{\mathrm{Ca}_{3}\left[(\mathrm{UO})_{2}\left(\mathrm{CO}_{3}\right)_{3}\right]_{2}\right\}^{2-}$ in the structure of línekite. The red dashed eclipse marks the "paddle-wheel" motif. Each uranyl tricarbonate cluster is involved in the two "paddle-wheels".
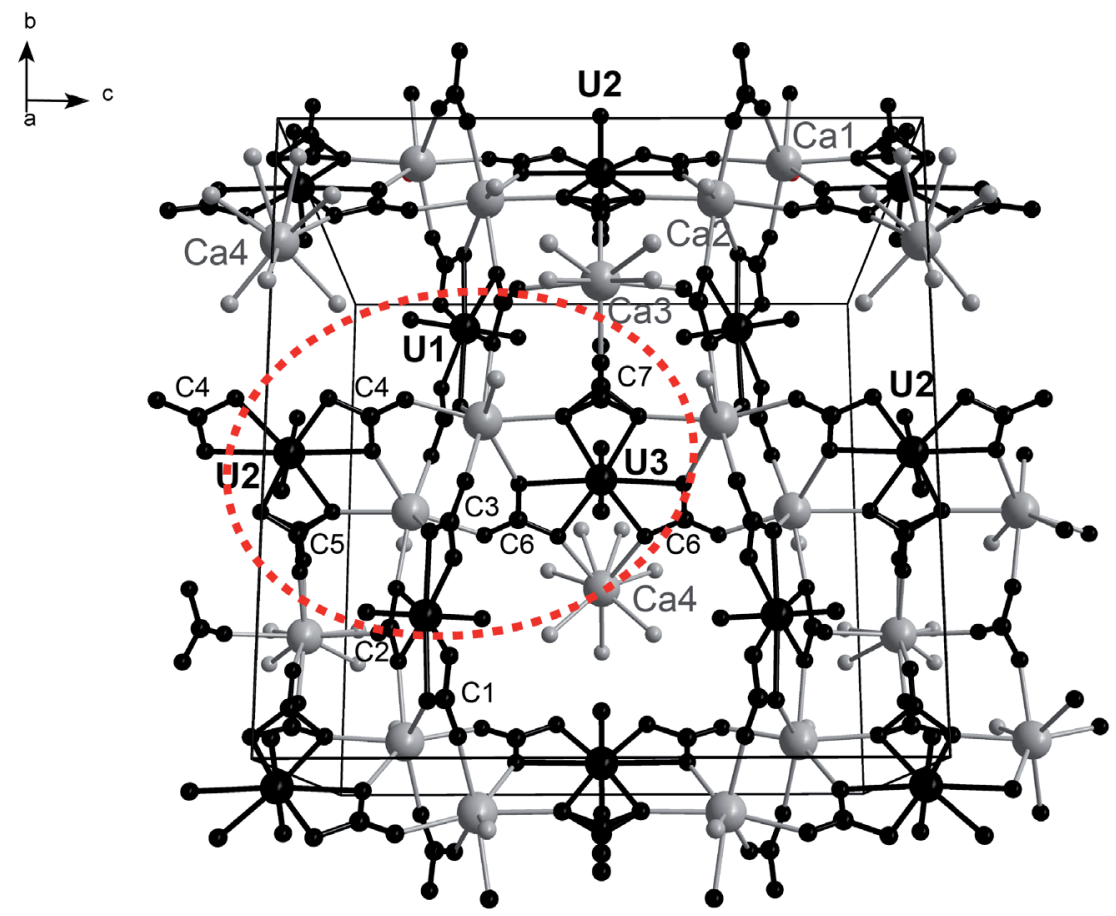

phase prepared by Meyrowitz et al. (1964) has a unitcell of the dimensions $a=17.98, b=18.29, c=16.95 \AA$; space groups inferred Pnmn or Pn2n. The powder data provided by Meyrowitz et al. (1964) fit very well to the diffraction data of línekite (Tab. 2) and the indices of refraction are also in the range, $\alpha=1.544(3), \beta=1.549(3)$, $\gamma=1.5^{\prime} 63(3)$.

The cationic content in the formula of línekite obtained from the structure refinement, $\mathrm{K}_{1.952} \mathrm{Ca}_{3}\left[\left(\mathrm{UO}_{2}\right)\left(\mathrm{CO}_{3}\right)_{3}\right]_{2}\left(\mathrm{H}_{2} \mathrm{O}\right)_{7.165}$ $(Z=8)$, is close to the ideal stoichiometry $\mathrm{K}: \mathrm{Ca}=2: 3$. The results of electron microprobe analysis, however, gave a lower $\mathrm{K}^{+}$content, $\left(\mathrm{K}_{1.73} \mathrm{Na}_{0.02}\right)_{\Sigma 1.75}\left(\mathrm{Ca}_{2.97} \mathrm{Cu}_{0.02}\right)_{\Sigma 2.99}$. This not unreasonable, due to the overlap of $\mathrm{K} K_{\alpha}$ and $\mathrm{U} K_{\alpha}$ peaks in the spectrum and consequent problems while measuring exact concentrations of $\mathrm{K}$, even in the WDS mode. We are convinced that the cationic content in línekite is similar to the other related uranyl

Fig. 7 The "paddle-wheel" in línekite structure, where the two $\mathrm{Ca}^{2+}$ cations take part in linkage to four uranyl tricarbonate clusters. The Ca1-Ca2 distance is $4.05 \AA$. Captions to abbreviations: $\mathrm{Ur}-$ apical $\mathrm{O}$ atom of the $\mathrm{UO}_{2}{ }^{2+}$ ion; eq - equatorial $\mathrm{O}$ atom of the $\mathrm{UO}_{8} ; \mathrm{O} X \mathrm{c}-\mathrm{O}$ atom no. $\mathrm{X}$ of the $\mathrm{CO}_{3}$ group; $\mathrm{w}-\mathrm{H}_{2} \mathrm{O}$ site; ' - split site. tricarbonates containing alkali- or earth-alkaline cations (Mereiter 1986a, b, 2013), showing no departures from the ideal stoichiometry. It is possible that a small amount of excessing $\mathrm{Ca}^{2+}$ cations could also entry the $\mathrm{K}$ sites in the structure; however, this is not the case. The only known non-stoichiometric exception among uranyl tricarbonates is a synthetic phase of Vochten et al. (1994),

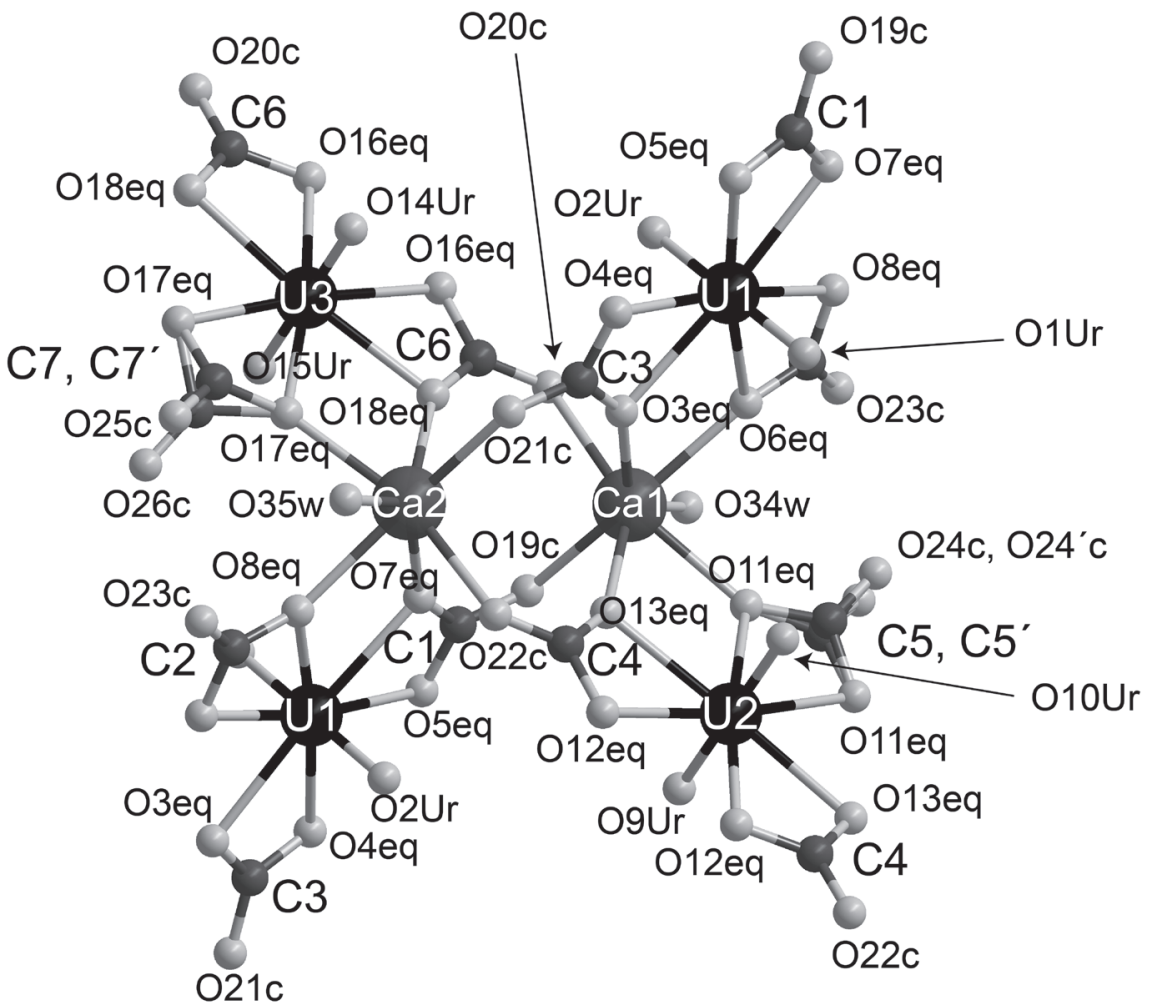



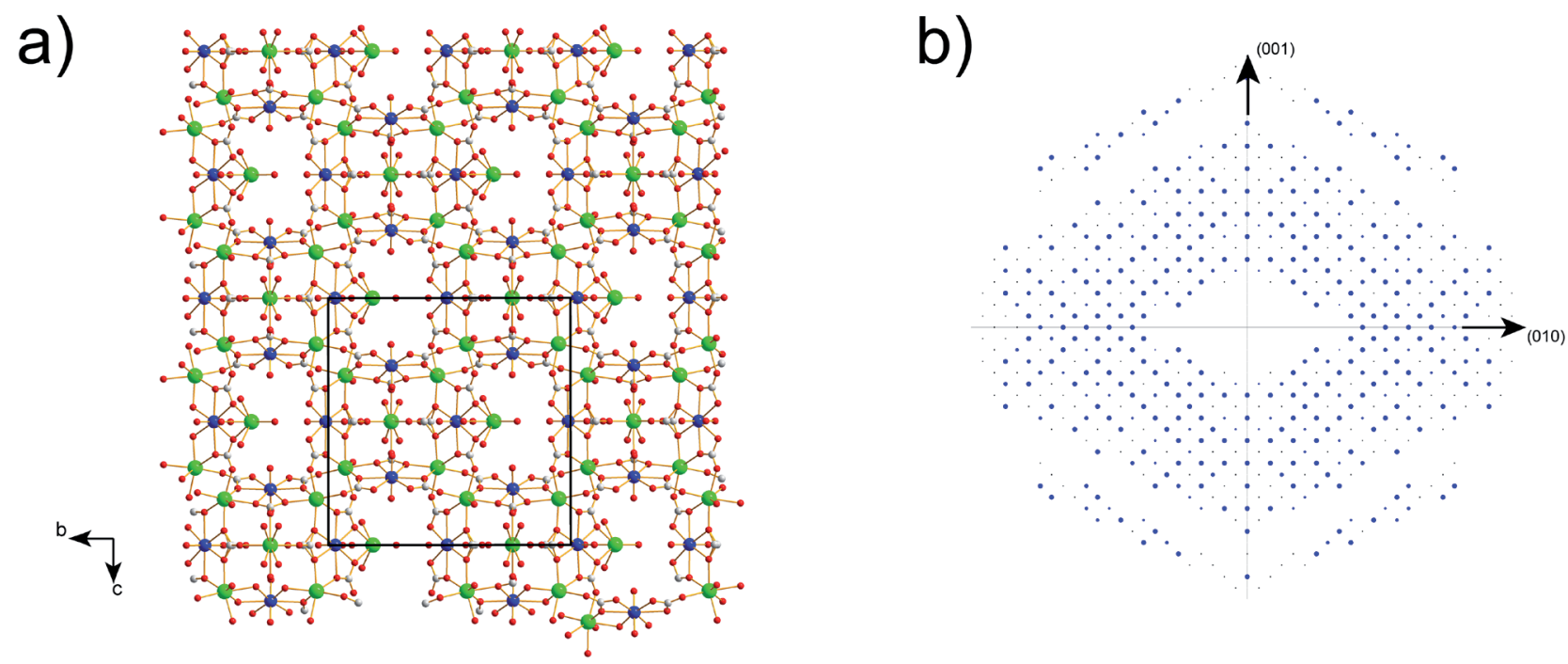

Fig. 8 The square grid of the (100) sheet in the structure of línkeite (a) leading to the strongly pseudo-tetragonal diffraction pattern (b). The latter was calculated by Jana2006 as $F_{\text {calc }}$ for the contributions of the $\mathrm{U}$ and Ca atoms only.

$\mathrm{Ca}_{1.54} \mathrm{Na}_{0.63}\left[\left(\mathrm{UO}_{2}\right)\left(\mathrm{CO}_{3}\right)_{3}\right]\left(\mathrm{H}_{2} \mathrm{O}\right)_{\sim 5.38}$. This compound, noteworthy, has a similar unit-cell metrics as línekite $(a=18.2, b=16.9, c=18.4 \AA, Z=8$, space group: Pnnm). Línekite has an extremely pseudosymmetric structure and a high degree of disorder; consequently, the structure refinement is problematic. The content of molecular $\mathrm{H}_{2} \mathrm{O}$ both in línekite and in the synthetic analog by Hughes-Kubatko and Burns (2004), obtained from the refinement of single-crystal X-ray data only, is thus underestimated. The only reliable values can be obtained from the chemical analysis (thermogravimetric or gas/ vapor-absorption measurement in a combustion train) in the case of such a high-degree disorder as present in the structure of línekite (since no desymmetrization takes place there).

Acknowledgements. The authors thank Ladislav Lapčák (Institute of Chemical Technology, Prague) for the collection of the Raman spectrum of línekite and Karla Fejfarová (BIOCEV, Prague) for help with X-ray data collection. Kurt Mereiter (TU Vienna) is highly acknowledged for the discussion on the línekite, a thorough critical reading of the manuscript and reviews on the earlier versions of the text. Comments by František Veselovský and an anonymous referee as well as handling editor František Laufek helped in improving the manuscript. This research was financially supported the project No. LO1603 under the Ministry of Education, Youth and Sports National sustainability program I of Czech Republic to JP, MD and by the long-term project DKRVO 2017-01 of the Ministry of Culture of the Czech Republic (National Museum 000232782) to JS and JČ.

Electronic supplementary material. Supplementary crystallographic data for this paper (including the selected interatomic distances, results of bond-valence analysis and a CIF file) are available online at the Journal website (http://dx.doi.org/10.3190/jgeosci.241).

\section{References}

Anderson A, Chieh Ch, Irish DE, Tong, JPK (1980) An Xray crystallographic, Raman, and infrared spectral study of crystalline potassium uranyl carbonate, $\mathrm{K}_{4} \mathrm{UO}_{2}\left(\mathrm{CO}_{3}\right)_{3}$. Canad J Chem 58: 1651-1658

BARTLETT JR, COONEY RP (1989) On the determination of uranium-oxygen bond lengths in dioxouranium(VI) compounds by Raman spectroscopy. J Mol Struct 193: 295-300

BRESE NE, O'KeEFFe M (1991) Bond-valence parameters for solids. Acta Cryst B47: 192-197

Brown ID (1981) The bond-valence method: an empirical approach to chemical structure and bonding. In: O'KeEFFe M, NAVRotSKy A (eds) Structure and Bonding in Crystals, Vol. 2. Academic Press, New York, pp 1-30

Brown ID (2002) The Chemical Bond in Inorganic Chemistry: The Bond Valence Model. Oxford University Press, Oxford, pp 1-230

Brown ID, ALTERMatT D (1985) Bond-valence parameters obtained from a systematic analysis of the inorganic crystal structure database. Acta Cryst B41: 244-247, with updated parameters from http://www.ccp14.ac.uk/ ccp/web-mirrors/i_d_brown/

Burla mC, Camalli M, Carrozzini B, Cascarano GL, Giacovazzo C, Polidori G, Spagna R (2003) SIR2002: the program. J Appl Cryst 36: 1103

Burns PC, EwIng RC, Hawthorne FC (1997) The crystal chemistry of hexavalent uranium: polyhedron geometries, bond-valence parameters, and polymerization of polyhedra. Canad Mineral 35: 1551-1570 
ČEJKA J (1969) To the chemistry of andersonite and thermal decomposition of dioxo-tricarbonatouranates. Coll Czechoslov Chem Commun 34: 1635-1656

ČEJKA J (1999) Infrared spectroscopy and thermal analysis of the uranyl minerals. In: BuRNs PC, FINCH RC (eds) Uranium: Mineralogy, Geochemistry and the Environment. Mineralogical Society of America and Geochemical Society Reviews in Mineralogy and Geochemistry 38: pp 521-622

ČEJKA J (2005) Vibrational spectroscopy of the uranyl minerals - Infrared and Raman spectra of the uranyl minerals II. Uranyl carbonates. Bull mineral-petrolog Odd Nár Muz (Praha) 13: 62-72 (in Czech)

Hughes-Kubatko KA, Burns PC (2004) The crystal structure of a novel uranyl tricarbonate, $\mathrm{K}_{2} \mathrm{Ca}_{3}\left[\left(\mathrm{UO}_{2}\right)\right.$ $\left.\left(\mathrm{CO}_{3}\right)_{3}\right]_{2}\left(\mathrm{H}_{2} \mathrm{O}\right)_{6}$. Canad Mineral 42: 997-1003

Koglin E, Schenk HJ, Schwochau K (1979) Vibrational and low temperature optical spectra of the uranyl tricarbonato complex $\left[\mathrm{UO}_{2}\left(\mathrm{CO}_{3}\right)_{3}\right]^{4}$. Spectrochim Acta A35: 641-647

Kraus W, Nolze G (1996) POWDER CELL - a program for the representation and manipulation of crystal structures and calculation of the resulting X-ray powder patterns. J Appl Cryst 29: 301-303

Krivovichev SV, PLÁŠIL J (2013) Mineralogy and crystallography of uranium. In: BuRns PC, Sigmon GE (eds) Uranium: From Cradle to Grave. Mineralogical Association of Canada Short Courses 43: pp 15-119

LANGMUIR D (1978) Uranium solution-mineral equilibria at low temperatures with applications to sedimentary ore deposits. Geochim Cosmochim Acta 42: 547-569

LAUGIER J, Bochu B (2014) CELREF: unit cell refinement program from powder diffraction diagram. Laboratoires des Matériaux et du Génie Physique, Ecole Nationale Supérieure de Physique de Grenoble (INPG), Grenoble, France. Accessed on May 30, 2014, at $h t t p: / / w w w . c c p 14$. ac.uk/tutorial/lmgp/celref.htm

LibowitzKy E (1999) Correlation of O-H stretching frequencies and $\mathrm{O}-\mathrm{H} \cdots \mathrm{O}$ hydrogen bond lengths in minerals. Monatsh Chem 130: 1047-1059

Mandarino JA (1981) The Gladstone-Dale relationship: Part IV. The compatibility concept and its application. Canad Mineral 19: 441-450

MEREITER K (1984) The crystal structure of albrechtschraufite, $\mathrm{MgCa}_{4} \mathrm{~F}_{2}\left[\left(\mathrm{UO}_{2}\right)\left(\mathrm{CO}_{3}\right)_{3}\right]_{2} \cdot 17 \mathrm{H}_{2} \mathrm{O}$. Acta Crystallogr A40 Supplement: C-247
Mereiter K (1986a) Crystal structure and crystallographic properties of schröckingerite from Joachimsthal. Tschermaks Mineral Petrogr Mitt 35: 1-18

Mereiter K (1986b) Neue Krystallographische Daten über das Uranmineral Andersonit. Anzeig Österr Akad Wiss Matem-Naturwiss K1 1986/3: 39-41

MEREITER K (2013) Description and crystal structure of albrechtschraufite, $\mathrm{MgCa}_{4} \mathrm{~F}_{2}\left[\mathrm{UO}_{2}\left(\mathrm{CO}_{3}\right)_{3}\right]_{2} \cdot 17-18 \mathrm{H}_{2} \mathrm{O}$. Mineral Petrol 107: 179-188

MeYrowitz R, Ross DR, Ross M (1964) A new uranyl tricarbonate, $\mathrm{K}_{2} \mathrm{Ca}_{3}\left(\mathrm{UO}_{2}\right)_{2}\left(\mathrm{CO}_{3}\right)_{6} \cdot 9-10 \mathrm{H}_{2} \mathrm{O}$. US Geol Surv, Prof Pap 501B: 82-83

Ondruš P, Skála R, Veselovský F, Sejkora J, Vitti C (2003) Čejkaite, the triclinic polymorph of $\mathrm{Na}_{4}\left(\mathrm{UO}_{2}\right)$ $\left(\mathrm{CO}_{3}\right)_{3}$ - a new mineral from Jáchymov, Czech Republic. Amer Miner 88: 686-693

Petříček V, Dušek M, Palatinus L (2014) Crystallographic computing system Jana 2006: general features. Z Kristallogr 229: 345-352

Plášsl J, FejFarová K, DušeK M, ŠKoda R, RohlíčeK J (2013) Revision of the symmetry and crystal structure of čejkaite, $\mathrm{Na}_{4}\left(\mathrm{UO}_{2}\right)\left(\mathrm{CO}_{3}\right)_{3}$. Amer Miner 98: 549-553

Plášš J, HLoušek J, Kasatkin AV, Belakovskiy DI, ČeJKa J, Chernyshov D (2015) Ježekite, $\mathrm{Na}_{8}\left[\left(\mathrm{UO}_{2}\right)\left(\mathrm{CO}_{3}\right)_{3}\right]$ $\left(\mathrm{SO}_{4}\right)_{2} \cdot 3 \mathrm{H}_{2} \mathrm{O}$, a new uranyl mineral from Jáchymov, Czech Republic. J Geosci 60: 259-267

Plášsl J, Mereiter K, Kampf A R, Hloušek J, ŠKoda R, ČejKa J, NĚmec I, Ederová J (2016) Braunerite, IMA2015-123. CNMNC Newsletter No. 31, June 2016, page 692; Mineral Mag 80: 691-697

PouchOU JL, PichoIr F (1985) "PAP" $(\varphi \rho \mathrm{Z})$ procedure for improved quantitative microanalysis. In: ARMSTRONG JT (ed) Microbeam Analysis. San Francisco Press, San Francisco, pp 104-106

Schrauf A (1873) Schröckingerit, ein neues Mineral von Joachimsthal. Tschermaks Mineral Petrogr Mitt 3: $137-138$

Skála R, Ondruš P, Veselovský F, CísaŘová I, Hloušek J (2011) Agricolaite, a new mineral of uranium from Jáchymov, Czech Republic. Mineral Petrol 103: 169-175

Vochten R, van Harverbeke L, van Springel K, Blaton N, PeEters OM (1994) The structure and physicochemical characteristics of a synthetic phase compositionally intermediate between liebigite and andersonite. Canad Mineral 32: 553-561 